\title{
ASSESSMENT OF SOCIO-ECONOMIC PROFILE AND RESIDENTS' SATISFACTION LIVING IN APARTMENTS AND SINGLE UNIT HOUSES IN ISLAMABAD, PAKISTAN
}

\author{
Syeda Zainab HASSAN ${ }^{1}$, Malik Asghar NAEEM ${ }^{1, *}$, Abdul WAHEED ${ }^{1}$, \\ Muhammad Jamaluddin THAHEEM ${ }^{2}$ \\ ${ }^{1}$ Department of Urban and Regional Planning, National University of Sciences and Technology (NUST), \\ Islamabad, Pakistan \\ ${ }^{2}$ Department of Construction Engineering and Management, National University of Sciences and \\ Technology (NUST), Islamabad, Pakistan
}

Received 11 August 2018; accepted 08 January 2019

\begin{abstract}
Cities in Pakistan, because of rapid pace of urbanization, are unable to provide adequate housing supply to cater to the needs of the people. Islamabad, the capital of Pakistan, has a population of two million with a growth rate of six percent. Construction of apartment buildings, as one of the alternatives to fulfil the housing needs, is on the rise. However, apartments are being designed without considering the needs of the residents. This research focuses on assessment of socio-economic profile and satisfaction of residents of single unit houses vis-à-vis of those living in apartments. Fried and Gleicher's approach was used in this research. This study analysed the socioeconomic characteristics, level of satisfaction of residents; drivers and barriers that influence the residential satisfaction of residents in two types of residential units in Islamabad. This study finds that residents of both housing types were equally satisfied with housing attributes and surrounding neighborhood while the residents of single unit houses were more satisfied with facilities, maintenance and culture. This study suggests that more focus should be given to factors like open space, basic amenities, privacy while designing an apartment building.
\end{abstract}

Keywords: apartments, single unit houses, residential satisfaction, socio-economic status, housing characteristics, neighborhoods, culture, Islamabad, Pakistan.

\section{Introduction}

The present population of Pakistan is 200 million with an urban population of 79 million. Pakistan is urbanizing at an annual rate of $3 \%$ which is the fastest growth rate in South Asia. The annual urban population is expected to increase to about 2.3 million per year (around 360,000 households at 6.35 individuals per household) over the next 20 years (World Bank, 2018). Pakistani cities suffer from housing deficits of about 3 million housing units (while nearly $50 \%$ of Pakistan's urban population lives in slums) (Jabeen, Sheng, \& Aamir, 2015). The estimated shortage of housing in Pakistan is up to 10 million units, about $40 \%$ of which is in urban areas. The demand for housing units is expected to increase in the near future due to the decline in family size and increased rates of household formation (World Bank, 2018). Every year, Pakistan falls short of almost 350,000 residential units because of inadequate housing supply. The quantitative housing shortage is exacerbated by qualitative deficits such as congestion, poor quality, and continuous deterioration (World Bank, 2018). Another factor that contributes to Pakistan's urban residential problem is its preference for urban sprawl and other forms of horizontal urban growth. The idea of compact development is still new for developing countries like Pakistan (Ewing et al., 2007). As per analysts of urban studies, such models could help in easing Pakistan's services crisis.

Rapid pace of urbanization in Pakistan has made housing one of critical challenges for the people residing in urban areas. Housing prices have increased exponentially in the past 10 years and has resulted in changing the dynamics of the middle class which is already unable to afford a house. In addition to the issue of expensive land prices, the people of Pakistan are now facing the

*Corresponding author. E-mail: asghar.naeem@nit.nust.edu.pk 
problem of land scarcity as well (Nadim, 2014). The developing pattern of the city is changing with time with new apartments springing up at different locations. People are still hesitant in accepting this new type of housing. The negative image of the apartments discourages the people to choose it over single unit houses. Single-family homes have been associated with higher levels of satisfaction than multifamily housing because of available amenities, such as room, privacy, and yard space (Morris \& Winter, 1978; Rent \& Rent, 1978).

Housing satisfaction has been one of the important factors in individual's general quality of life. Thus the extent to which resident's needs and aspirations are met by their housing conditions is a concern for both researcher and housing developers (Baiden, Arku, Luginaah, \& Asiedu, 2011). There have been a number of studies that have given us insight about the residential satisfaction in developed countries (Amole, 2009; Baiden et al., 2011), but to best of our knowledge no study has been conducted in Pakistan for this particular subject. Our study helps in understanding the present housing conditions of Pakistan and the gap that the residents feel between the most popular housing types. Most of the studies that are conducted on residential satisfaction are based on physical characteristics of certain type of houses and residential satisfaction. While this study highlights the difference in opinion of residents of apartments and S.U. houses of Islamabad. Not many studies have been conducted to highlight this difference in opinion among the residents of 2 different housing types in a same city. The gap in the literature motivates us to conduct this study. Our study examines the affiliation between 2 different housing types and residential satisfaction, finds out the indicators that affect the resident's perspective about apartment buildings and the indicators that can improve the overall satisfaction of the residents of the city.

The study objectives are (1) to measure the level of residential satisfaction among the residents of S.U. houses and apartments in Islamabad, Pakistan; (2) to identify the factors that affect residential satisfaction in general; (3) to propose policy recommendations based on the findings of the study. The government has proposed to build 5 million affordable houses in the country to bridge the housing gap. The study would help in highlighting the issues that general public faces in their residential units and would help in improving the overall residential satisfaction.

\section{Literature review}

In order to evaluate a housing industry, an appropriate criterion must be devised. Different criteria have been used over the years; the concept of residential satisfaction has become the most popularly used (Amole, 2009). A number of studies prove that people attach top most priority to adequacy and satisfaction with accommodation (Kiel \& Carson, 1990). The concern for resident's satisfaction is deeply related to the larger concern for the quality of life. In Britain, "Abrams discovered that between 10\% and 14\% of the middle class and 19\% of the working class included housing within their three most important areas for overall life satisfaction (Mulvihill, 1977). A study conducted in Vietnam suggested that residential satisfaction is a strong predictor of life satisfaction. Housing is an important part of life and thus contributed to the overall well-being of human (Tran \& Van Vu, 2018).

Rapoport (1997) believes that people evaluate their residential environments against an image of what they would like it to be. These evaluations are highly influenced by their previous experiences in addition to their level of adaptation and cultural values (Potter \& Cantarero, 2006). There are several variables that have been found to affect residential satisfaction including cultural aspects (Deshmukh, 1995; Guney, 1997), neighborhood and environs, house and neighbors and other social factors like privacy and neighbor interaction (Amérigo \& Aragonés, 1990). Other than that housing-related attributes as well as characteristics of residents influence the residential satisfaction of an occupant. For example, household size was found to have a negative relationship with residential satisfaction (Diaz-Serrano, 2006; Mohit, Ibrahim, \& Rashid, 2010; Rohe \& Basolo, 1997). Similarly, age has ambiguous relationship with residential satisfaction. Some studies shows the older residents to be more satisfied with housing (Lu, 1999; Varady \& Preiser, 1998; Varady, Walker, \& Wang, 2001), while the others show inverse relationship of age and residential satisfaction (Mohit et al., 2010). Similarly, a number of studies found that household income has a positive relationship with residential satisfaction (DiazSerrano, 2006; Hu, 2013; Lu, 1999; Varady et al., 2001; Vera-Toscano \& Ateca-Amestoy, 2008), some others reveal that it has an inverse relationship (Amole, 2009) or no significant relationship with residential satisfaction (Li \& Wu, 2013; Zhu \& Shelton, 1996). The length of residence was also found to have a positive relationship with residential satisfaction in some studies (Amole, 2009; Mohit et al., 2010; Peck \& Kay Stewart, 1985), while in other a negative relationship has been found (Onibokun, 1976).

Different studies conducted in different countries confirm that residential satisfaction is substantially affected by a number of physical characteristics of the environment, e.g. dwelling and neighborhood characteristics (Addo, 2016; Amole, 2009; Baiden et al., 2011; Baillie, 1990; Diaz-Serrano, 2006; Galster, 1987; Yi, 1985). In general the studies indicates that larger houses, better interior structures and house type, locations and a clean environment in the housing area go together with greater residential satisfaction. In addition to residents satisfaction with their neighborhood, considering such factors as green space, pollution, upkeep and cleanliness is also found to be as major factor associated with overall residential satisfaction (Rioux \& Werner, 2011).

A study conducted in Tabriz, Iran investigated residential satisfaction among different types of residential units. A comparison of the residents' satisfaction rating among different housing types in Tabriz indicated that despite the new trend of multi-unit housing construction recently, 
Table 1. Indicators of residential satisfaction and socio-economic profile of residents (Amérigo \& Aragonés, 1988, 1990; Aragonés, Corraliza, Cortés, \& Amérigo, 1992; Azimi \& Esmaeilzadeh, 2017; Coker, Awokola, Olomolaiye, \& Booth, 2008; Jaafar, Mohamad, Liza Hasan, \& Ramayah, 2005; Marans, 2003)

\begin{tabular}{|c|c|c|c|c|c|c|}
\hline \multicolumn{2}{|c|}{ Physical } & \multicolumn{3}{|c|}{ Management/organizational } & \multirow{2}{*}{$\begin{array}{c}\text { Social/ } \\
\text { psychological }\end{array}$} & \multirow{2}{*}{ Socio-economic } \\
\hline Housing & Neighborhood & Facilities & Maintenance & Safety & & \\
\hline $\begin{array}{l}\text { Light } \\
\text { satisfaction }\end{array}$ & $\begin{array}{l}\text { Visual } \\
\text { attraction }\end{array}$ & Accessibility & $\begin{array}{l}\text { Building } \\
\text { maintenance }\end{array}$ & Security & Privacy & Number of residents \\
\hline Air satisfaction & $\begin{array}{l}\text { Cleanliness of } \\
\text { neighborhood }\end{array}$ & $\begin{array}{l}\text { Garbage } \\
\text { disposal }\end{array}$ & $\begin{array}{l}\text { Street } \\
\text { maintenance }\end{array}$ & Safety & Noise & People employed \\
\hline Residence size & $\begin{array}{l}\text { Recreational } \\
\text { space }\end{array}$ & Water supply & $\begin{array}{l}\text { Parking lot } \\
\text { maintenance }\end{array}$ & $\begin{array}{l}\text { Enforcement } \\
\text { of rules }\end{array}$ & $\begin{array}{l}\text { Interaction with } \\
\text { neighbors }\end{array}$ & Work/edu distance \\
\hline Open space & - & - & - & - & Welcoming & Monthly income \\
\hline Room no. & - & - & - & - & - & Ownership \\
\hline- & - & & - & - & - & No. of cars \\
\hline- & - & - & - & - & - & Duration of stay \\
\hline- & - & - & - & - & - & Home province \\
\hline
\end{tabular}

they were not perceived as convenient as traditional courtyard houses in terms of privacy, house size, natural light, neighborhood security and satisfaction with neighbors. In contrast, with respect to satisfaction in terms of physical safety of building, amenities and accessibility to different public services; apartment houses and housing complexes were rated higher than S.U. houses (Azimi \& Esmaeilzadeh, 2017).

Social factors also play an important role in determining residential satisfaction. Some researchers (Amérigo \& Aragones, 1997; Fried \& Gleicher, 1972) claim that social relationships have an even more important relationship with residential satisfaction than the physical environment. Goudy (1977) was one of the first researchers to consider that social factors play an important role in predicting residential satisfaction. Similarly, if a resident perceive their neighborhood as unsafe they are less likely to be satisfied, which can result in high residential mobility out of the area (Diaz-Serrano \& Rodríguez-Pose, 2011). A study by Chapman and Lombard (2006) indicated that less than $10 \%$ of the residents believed crime existed in their neighborhood despite the statistics indicating higher percentage of crime rate in the neighborhood. This perception of low crime in the community resulted in high levels of residential satisfaction. It was found out through a study in Dhaka that the apartment owners must provide security and safety (Rahman, Hussain, Uddin, \& Islam, 2015). Similarly, aspects such as open spaces, proximity to services and amenities, visual attractiveness and overcrowding also plays an important role in residential satisfaction (Adriaanse, 2007; Bonaiuto, Aiello, Perugini, Bonnes, \& Ercolani, 1999; Bonnes, Bonaiuto, \& Ercolani, 1991; Braubach, 2007; Chapman \& Lombard, 2006; da Luz Reis \& Dias Lay, 2010; Rent \& Rent, 1978). Excessive noise from overcrowding in high density housing complexes and lack of open spaces, causes a negative impact on attachment with a neighborhood and in return decreases residential satisfaction. Table 1 given above encompasses indicators of residential satisfactions used in various stud- ies discussed in the literature review. The indicators have also been used later for statistical analysis in subsection 4.2 and 4.3 of the paper.

\section{Case study area}

Islamabad, the capital city of Pakistan, was developed in 1962, $14 \mathrm{~km}$ away from Rawalpindi city (Mahsud, 2007; Yakas, 2001). Figure 1 given below portrays map of Islamabad. The planning of the city was carried out by Greek modernist architect and town planner, Constantinos Doxiadis. Islamabad was designed in a grid format, with $11 \mathrm{sec}-$ tors, each $4 \mathrm{~km}^{2}$, extending southwest from the Margalla Hills. The growth of the twin cities has not just been driven by natural factors but also by migration from adjacent cities. The search for economic opportunity, incidence of natural disasters and socio-political conflict in other regions also encouraged people of other cities to move to the twin cities (Sawas, Anwar, Iqtidar, \& Viqar, 2014).

Butt, Waqas, Iqbal, Muhammad, and Lodhi (2012) used multi sensor and satellite data to assess urban sprawl and the changing land uses in Islamabad city. They find that urban infrastructural growth and the city's population

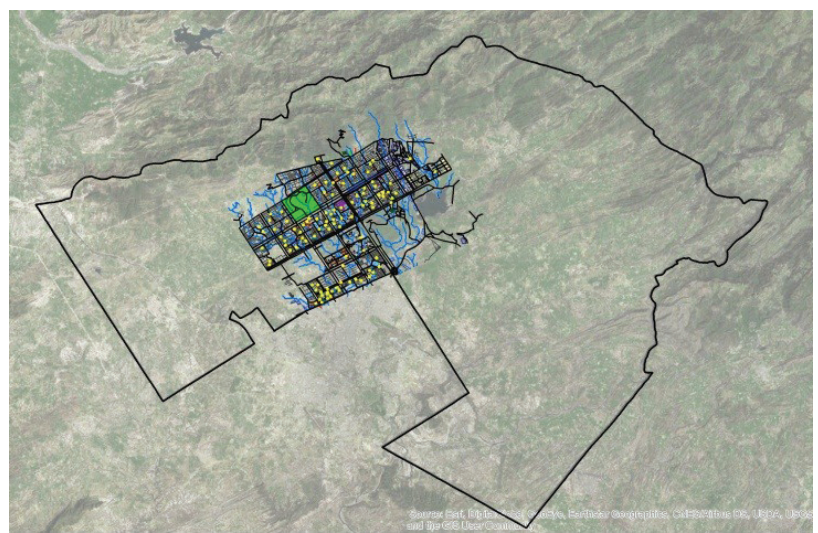

Figure 1. Map of Islamabad (source: ARC GIS) 
Table 2. Sample size (Pakistan Bureau of Statistics, 2017; Yamane, 1967)

\begin{tabular}{|c|c|c|c|c|c|}
\hline Total population & $\begin{array}{c}\text { Urban population } \\
(\mathrm{N})\end{array}$ & Margin of error (e) & $\begin{array}{c}\text { Sample size } \\
(\mathrm{n})\end{array}$ & S.U. houses (80\%) & Apartments (20\%) \\
\hline $2,001,579$ & $1,009,832$ & 8 & 156 & 125 & 31 \\
\hline
\end{tabular}

have not increased at the same pace. Huge patches of natural vegetation have been replaced by impervious surfaces. Urban expansion has increased from $165 \mathrm{~km}^{2}$ in 1972 to $252.31 \mathrm{~km}^{2}$ in 2009 while the agricultural land/vegetation has decreased from $640.71 \mathrm{~km}^{2}$ in 1972 to $561.35 \mathrm{~km}^{2}$ in the same time period. From past 37 years, every year an urban development of $2.36 \mathrm{~km}^{2}$ occurs in the capital city (1972-2009). There has also been a growth of unplanned settlements in the city (Sawas et al., 2014). In 1998, the total population of Islamabad was 805,000 and in 2010 it reached 1.03 million and in 2017 the total population was 2 million. From 1998 to 2017, Islamabad has seen an increase of $91 \%$ in the total urban population which is the highest ratio as compared to other cities in Pakistan (Pakistan Bureau of Statistics, 2017). The continuous growth of the man-made structures and increasing population pose numerous challenges.

\section{Methodology}

Current study was conducted as a hybrid research design as both, qualitative and quantitative data were collected for analysis of the present situation of the single unit houses and private apartments in the capital city of Pakistan. Field survey, including questionnaire survey, was conducted at different locations in the study area so that basic characteristics of the study area could be identified and analyzed. This survey helped in determining the socioeconomic status of the local people, their concerns about the existing situation and preferences for a better housing type. As the segments selected for field survey were mainly residential areas of the city, the sample size was taken to be 156 by using Yamane (1967) formula.

$$
n=\frac{N}{\left(1+N e^{2}\right)} \text {. }
$$

The descriptive statistics including details of total population of Islamabad, the urban population, sample size, and number of sampled S.U. houses and apartments is given in Table 2. Islamabad has a higher number of single unit houses thus the sample percentage for single unit house (S.U. Houses) was taken to be $80 \%$. Because of the security situation of the city residents were reluctant in sharing their information and thus the margin of error was increased to $8 \%$ and only 120 S.U. houses and 27 apartments could be interviewed. The sample size used for this study is within range of 30-500 suggested by Roscoe (1975) for research in behavioral science. Population sample was selected randomly so the study would be free of any kind of bias.

According to Gifford (2007) "To understand residential satisfaction, it must be adequately measured". Researchers have used several methods to measure residential satisfaction. Usually, it is measured by answering several questions on a Likert scale that mainly denotes physical environment of dwelling space, neighborhood environment, maintenance/management, safety and security and social interaction (Lewicka, 2011).

The level of satisfaction of the residents was calculated by using Index of Satisfaction first developed by S. H. Yeh (1972); this index was employed in the current study for comparison of level of satisfaction of the residents. An index score of +1.00 stands for 'satisfied'; 0.00 score shows 'very low' level of satisfaction while negative score indicates 'dissatisfaction' of the respondents as shown in Table 3 (S. H. Yeh, 1972; S. H. K. Yeh, 1975). This index has been used in various research studies (Anwar, Perveen, Mehmood, \& Akhtar, 2008), and has proven to be effective in demonstrating the levels of satisfaction or dissatisfaction in different studies (Abdu, Hashim, Samah, \& Salim, 2014).

$$
Y I S=\frac{X_{1}-X_{2}}{X},
$$

where: $X_{1}$ - satisfied cases, $X_{2}$ - dissatisfied cases, $X$ - total number of cases.

Table 3. Range of YIS (Abdu \& Hashim, 2014)

\begin{tabular}{|c|c|}
\hline YIS & Level of satisfaction \\
\hline Less than 0.2 & Very low \\
\hline $0.20-0.39$ & Low \\
\hline $0.40-0.59$ & Medium \\
\hline $0.60-0.79$ & High \\
\hline 0.80 and above & Very high \\
\hline
\end{tabular}

T-test was used to analyze whether there was a significant difference in the satisfaction level of the residents of the two housing types, i.e., S.U. houses and apartments. Regression analysis was conducted on the data to find out the indicators that affect the residential satisfaction the most.

The study area selected for this research was the capital city of Pakistan i.e., Islamabad. It has an area of $906 \mathrm{~km}^{2}$ with a population of 2 million (Pakistan Bureau of Statistics, 2017) and the urban population of $1,009,832$. The city is divided into 5 zones. Only zone-I is considered in this study as it is most populated and the central hub of the city (see Figure 2).

Table 4 demonstrates the population and number of housing units in rural as well as urban regions of the city. Only urban area of the city was considered for this study. Out of 22 sectors in Zone I of Islamabad, 8 residential sectors, highlighted in Figure 2, were selected from the city for the survey including E11, F11, F10, G11, G10, G9, F8 and I9. These are the main residential areas of the city 


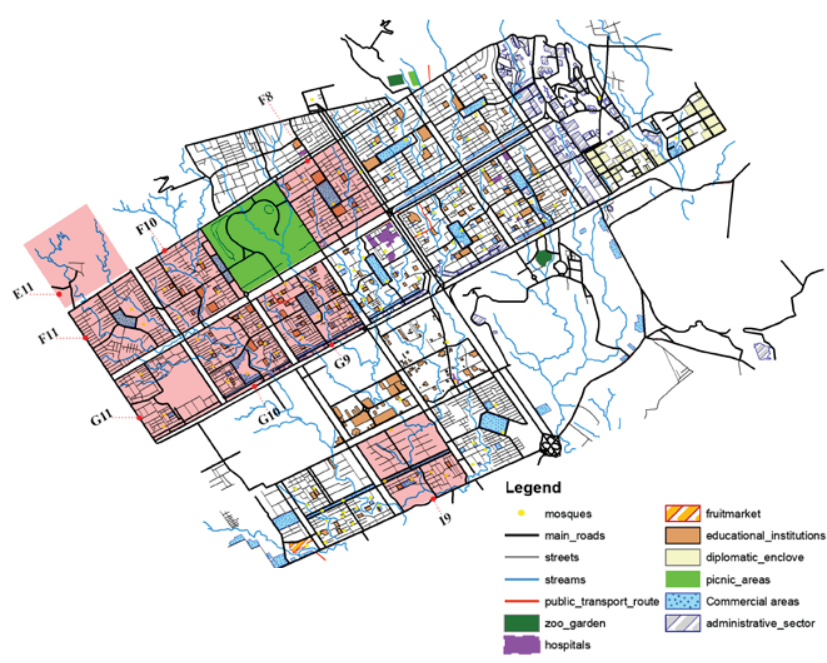

Figure 2. Map of Islamabad with highlight study sectors (source: ARC GIS)

with majority of S.U. houses and apartments. One can find a mix of different sizes, types (S.U. houses to houses with multiple households) and age. Apartments of the city are relatively new and are concentrated in specific sectors like E11, F11, F10 and G11.

Table 4. Population of Islamabad

(Pakistan Bureau of Statistics, 2017)

\begin{tabular}{|l|c|c|}
\hline \multicolumn{1}{|c|}{ Region } & Population & $\begin{array}{c}\text { No. of housing } \\
\text { unit }\end{array}$ \\
\hline $\begin{array}{l}\text { Islamabad Capital Territory } \\
\text { (ICT) }\end{array}$ & $2,001,579$ & 335,408 \\
\hline Rural & 991,747 & 165,490 \\
\hline Urban & $10,09,832$ & 169,918 \\
\hline
\end{tabular}

\section{Findings and discussion}

The public opinion survey helped in the collection of demographic data of the respondents which is shown in Figure 3. The demographic data of the S.U. houses shows that almost $65 \%$ of the respondents were male while the other
$45 \%$ were female, whereas in the apartments this ratio increased to $81: 30$. One of the reasons behind this trend is that the survey was conducted on the weekend and thus more respondents were male as compared to females. Similarly, $80 \%$ of the people living in the apartments were aged between 20-40 years. While, on the other hand, the respondents of S.U. houses were homogenously distributed between the age-bracket of 20-60 years. One of the possible reasons for the younger group being in majority in appartments was that most of the people were living in the study area for educational or occupational purposes. Also, the rent of the apartments was lower in comparison to S.U. houses, which makes these types of residential units more economical for the younger age group who come to the city for educational or occupational purposes.

Almost $50 \%$ of the respondents of both housing types had a bachelor's degree. The other $30 \%$ had intermediate level of education and almost $20 \%$ fell in post graduate education level. Most of the residents had come from different provinces in search of jobs and better educational opportunities. Majority of the respondents of apartments and S.U. houses were privately employed. The second highest ratio of the respondents fell in 'Student' category in apartments while in S.U. houses, the respondents were evenly distributed between the categories of Housewives and Students.

The Figure 4 shows that almost $80 \%$ of S.U. houses had 4-7 people in their families. But this number went down to 2-5 persons/unit in apartments. The major reason behind smaller number of people in an apartment is its size. They are usually smaller in size and accommodate fewer people as compared to S.U. houses. Majority of the S.U. houses in the study area had 3-4 bedrooms which accommodated more people as compared to apartments. Also, the family structure of the S.U. houses was quite different than that of apartments. The family size was bigger in the S.U. houses as compared to that of the apartments.

Figure 4 further shows that $70 \%$ of the S.U. houses had 1-2 people employed while in the case of private apartments this percentage increases to $85 \%$. The most probable reason could be that most of the apartment's

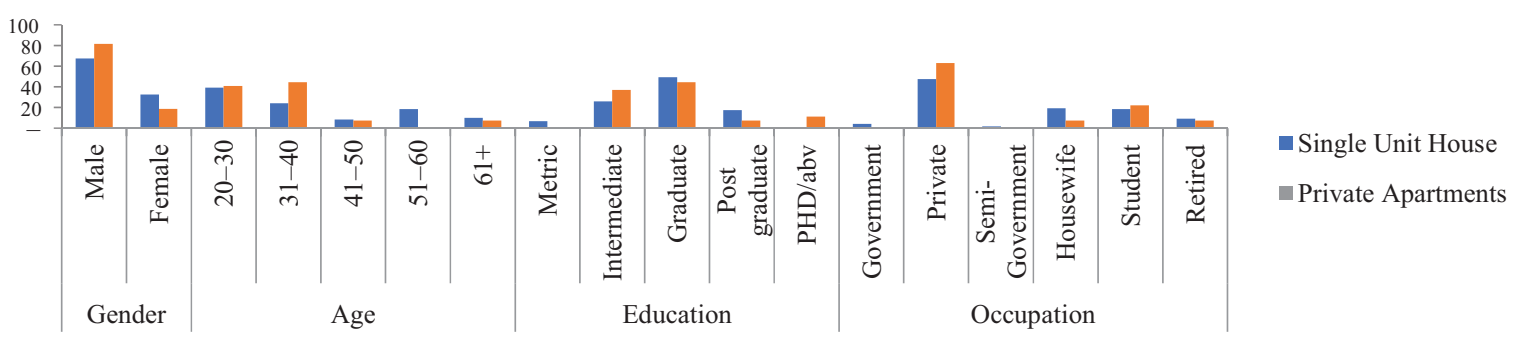

Figure 3. Respondent detail of the residents of single unit (S.U.) houses and apartments (source: field survey)

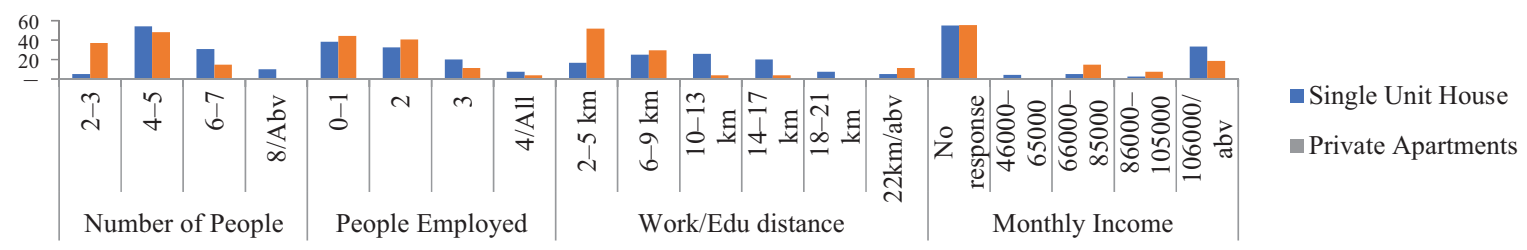

Figure 4. Employment detail of the residents of S.U. houses and apartments (source: field survey) 
dwellers were in the city for the sole purpose of earning livelihood. Most of the residents of both housing types were reluctant in sharing their monthly income. The result, however, showed that $33 \%$ of the respondents of single unit housing and $19 \%$ respondents of apartment buildings had a monthly income of 106,000 or above. The results also demonstrated that people living in S.U. houses had higher income level than that of apartments.

Figure 5 shows that almost $60 \%$ of the people living in S.U. houses owned their residential units, while this ratio was $50 \%$ in apartments. This is also one of the reasons that people of S.U houses lived far away from their work places and had a longer commute as compared to people living in apartment buildings. Whereas, apartment dwellers had the choice of moving their residence easily so, they lived closer to their work places. $77 \%$ of the respondents of S.U. houses paid 25,000-55,000 PKR rent monthly. While 100\% apartment dwellers paid 15,000-45,000 PKR per month. This further elaborates the reason behind younger generation opting for apartment buildings. The residents of S.U. houses had multiple sources of income and could afford higher rents. As the rents for apartments were lower this was also one of the reasons that people preferred renting an apartment rather than a S.U. house.

Figure 5 also shows the number of rooms and the availability of open space in each category of the housing type. Almost $40 \%$ of S.U. houses had 3 rooms and 35\% had 4 rooms. $60 \%$ of the apartments had 3 rooms and $26 \%$ had 2 rooms. This reflects that S.U. houses had almost the same distribution of rooms while apartment buildings had smaller sizes of apartments and hence fewer rooms. Re- sults of the survey related to the provision of open spaces showed that $74 \%$ of the respondents of S.U. houses complained about the unavailability of open spaces in their homes. $81 \%$ of the residents of apartments also showed their dissatisfaction regarding the absence of a proper open space in their homes. This factor can be attributed to the smaller sizes of houses being observed in the survey.

Figure 5 shows that almost $41 \%$ of the apartment buildings had 8 floors or more. And the remaining had 4-7 floors. $45 \%$ of the respondents of the apartments lived on $2^{\text {nd }}$ floor, $22 \%$ live on $3^{\text {rd }}$ floor and $19 \%$ on the $4^{\text {th }}$ floor. Higher floors were selected purposely as people generally prefer apartment on ground floor. The study of higher floors helped in understanding the problems of the residents in a better way. Although prices and rents of ground floor apartments are higher, many of the residents complained that living on the ground floor disturbed their privacy as all the people of the building crossed their homes while moving to their respective apartments.

As reflected in Figure 6, given below, almost $50 \%$ of the respondents of S.U. houses stated that they have been living in their current dwellings for almost 13 years or more and $35 \%$ said they have been living in their dwellings for about $1-6$ years. This is because most of the residents living in S.U. houses owned their houses and were living there with their families, whereas most of the residents of apartments had been living in their current dwellings for 1-6 years. The reason behind this was that the apartment buildings were constructed recently in the city. $51 \%$ of the residents of S.U. houses belonged to Punjab province, 15\% belong to KP and $20 \%$ claimed to belong to Islamabad.

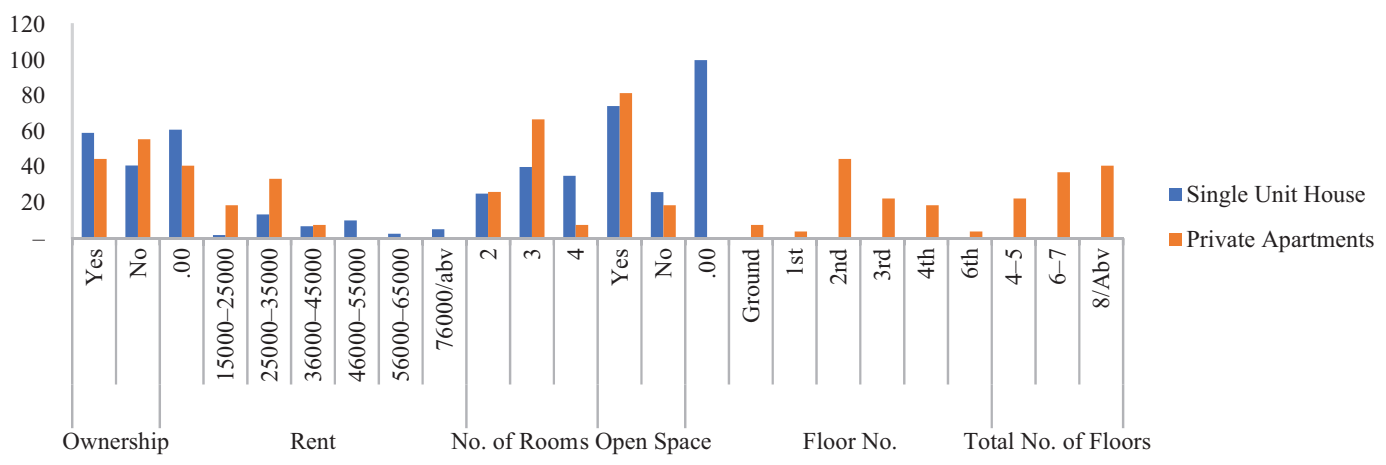

Figure 5. Ownership and physical features of S.U. houses and apartments (source: field survey)

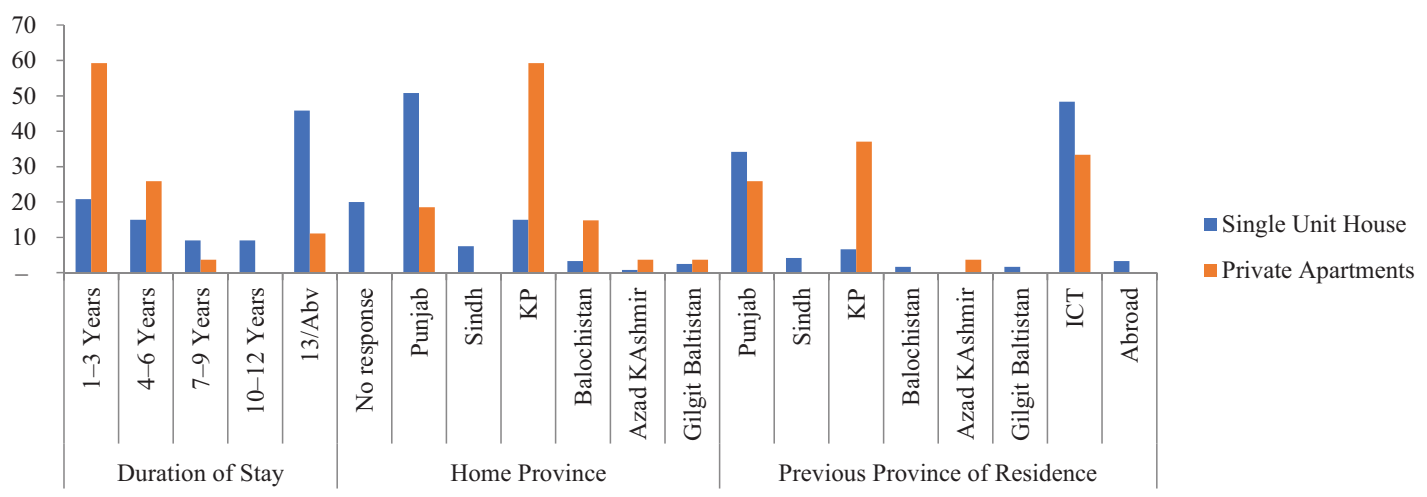

Figure 6. Occupation history of the residents of S.U. houses and apartments (source: field survey) 


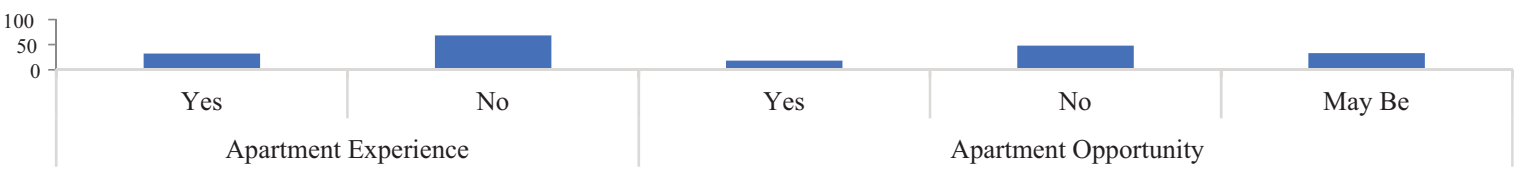

Figure 7. Prior experience of living in S.U. houses and apartment buildings and apartment residence opportunity (source: field survey)

Whereas $60 \%$ of the respondents of apartments belonged to KP and the other major contribution was from Punjab. The reason behind this was that KP and Punjab are geographically adjacent to Islamabad which made it a good option for the people of these regions to move to the study area so that they would be able to avail better educational and employment opportunities.

Figure 7 shows that $67 \%$ of the respondents of S.U. houses had never lived in an apartment before. Pakistan being a developing country doesn't have a high number of apartment buildings. The growth of Islamabad has increased in the couple of decades and many new apartment buildings have been constructed in the city and the number has been increasing ever since. $34 \%$ of the respondents of S.U. houses stated that they would not opt to live in an apartment building as they were very satisfied with their current housing type. $23 \%$ were not sure about their answer but stated that if provided better facilities they may happily move to an apartment. The cause behind the higher percentage of people not opting for an apartment might be that many of the respondents owned the houses they were living in and did not think they had any reason to shift to a housing type they thought would not accommodate their household size and fulfill all their requirements.

\subsection{Satisfaction level with respect to housing type}

The indicators used for finding out the satisfaction level of the residents of S.U. houses and apartments are given in the Table 1. Yeh's Index of Satisfaction was used to determine the level of satisfaction of both the housing types. The Figure 8 shows that medium level of satisfaction was recorded when the respondents of S.U. houses and apartments were asked about the existing situation of light, air and the size of open spaces they had in their residences. The Figures 9-12 portray the open area and condition of corridors in S. U. houses and in apartments in selected area. The dissatisfaction of the respondents of S.U. houses was mainly because of the absence of lawn at the front of their homes. Many respondents complained that since their houses were north facing, they did not receive adequate sun light in their homes. The residents of the S.U. houses as well as apartments were dissatisfied with the size of their residence. This result can be termed as unusual as many believed that the spaces in S.U. houses were larger than that of apartments. One of the other reasons behind the dissatisfaction was that the household size of S.U. houses was much larger than that of the apartments. Nuclear families lived in apartments thus the size of their residence did not bother them.

Low level of satisfaction was recorded when the respondents of the S.U. houses were asked about the existing visual situation of their neighborhood. This was because of the variety in the facades of the houses in the surrounding area. As the houses were owned by different people thus, each house had a different façade. This variety of facades made the neighborhood look odd. Also, most of the houses in sector G9, I8, G7, F8 were

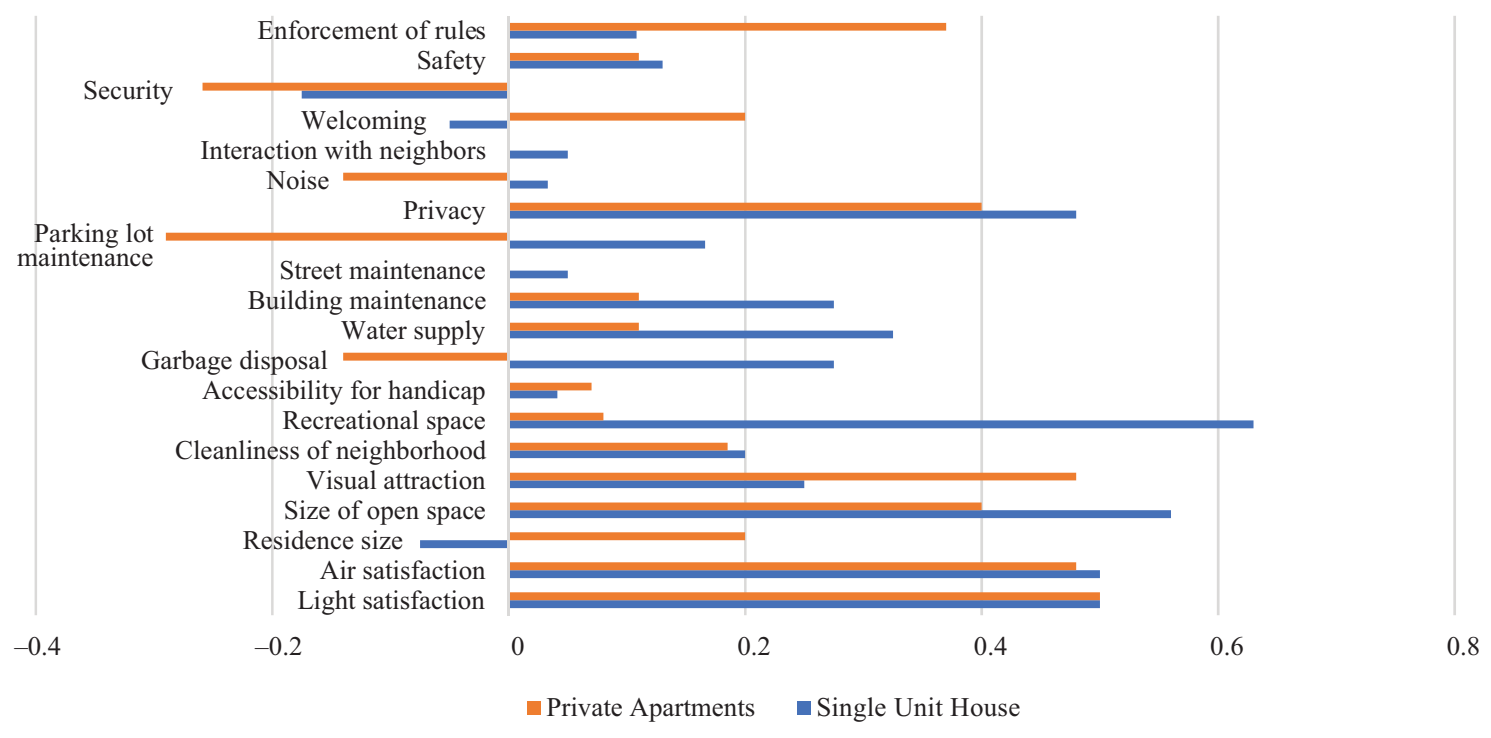

Figure 8. Satisfaction with respect to housing type (source: field survey) 
constructed a long time ago and their physical condition was very poor and needed maintenance. Respondents living in apartments expressed medium level of satisfaction regarding the visual attraction of their neighborhood. Most of the apartments were newly constructed keeping in mind the needs of the residents. It was because of this reason that they found those buildings more attractive.

When asked about the cleanliness of neighborhood, the respondents of the S.U. houses expressed low level of satisfaction because of the internal road conditions of the city. New construction was being done in many of the sectors and construction material was being dumped on the roads which not only caused physical damage to the roads but also became a nuisance to the residents of those areas. Almost $60 \%$ of the residents of apartments rated the cleanliness of their neighborhood to be very low. This was because most of the apartment buildings were situated in sectors like G11, G10, and E11. The infrastructure of these sectors was very poor which caused issues like stagnant water etc. The Figure 8 also shows that the residents of S.U. houses expressed high level of satisfaction when asked about the availability of recreational spaces. Most of the residents stated that they had recreational spaces in their neighborhood and were well maintained.

As demonstrated in Figure 8, the respondents of S.U. houses and apartments expressed very low level of satisfaction when asked about the accessibility for handicaps. The difference in the percentage for S.U houses was less because this type of housing had lower finished floor levels, thus a maximum 2 or 3 number of steps were required. Most of the residents were owners of their dwellings that is why they had designed their houses while keeping in mind their requirements. As apartment buildings had multiple floors, accessibility became a major issue for the handicaps or residents of older age group.

Almost $50 \%$ of the respondents of S.U. houses were highly satisfied with the garbage disposal facilities around their homes. The garbage was collected every day in all sectors which resulted in high level of satisfaction in terms of cleanliness whereas, the respondents of apartments expressed dissatisfaction regarding the garbage disposal of their buildings because the garbage was picked up after every 2 days or sometimes only once a week.

The respondents of the S.U. houses and apartments expressed low level of satisfaction regarding the water supply. Many of the residents had their own source of water supply besides the one provided by the CDA. Residents complained that they face shortage of water by the source provided by CDA. Many respondents of the apartments claimed that upper floors faced more shortage of water as compared to the lower floors.

Respondents of S.U. houses expressed low level of satisfaction when asked about building maintenance while that of apartments expressed very low level of satisfaction. The main reason behind the low level of satisfaction of S.U. houses was that $41 \%$ of the respondents did not own the houses they lived in and thus were dependent on the landlords for the maintenance of their homes which was done by the landlords very rarely. In the case of street maintenance, again, the respondents of S.U. houses and apartments expressed very low level of satisfaction. The respondents of S.U. houses complained about the issues like stagnant water and construction debris around their homes. The people living on the main roads of the city were happy with their street maintenance. According to them, the administration took immediate action whenever a complaint was lodged regarding street maintenance as those roads were the primary roads of the city and needed to reflect a good image to the world.

The residents of apartments expressed dissatisfaction regarding maintenance of the parking lot provided for the residents of the apartment building as the management did not provide any maintenance facility. Most of the cars were parked in open without any shade. Some of the residents also complained that the number of parking spaces provided in the parking lot was very low, thus many residents had to park their vehicles outside the premises.

The respondents of both the housing types expressed medium level of satisfaction regarding the issue of privacy (Figure 8). The value of satisfaction was comparatively lower in apartments, i.e., 0.4, as many respondents complained that they had to come across many people while moving from ground floor to the floor of their residence. When asked about the satisfaction level regarding noise, the respondents of $\mathrm{S}$. U. houses expressed very low level of satisfaction with the value of 0.03 . They complained about loud noises from the neighboring houses. The respondents of apartments expressed dissatisfaction regarding their noise levels of their buildings. They complained that many of their neighbors were very noisy which created disturbance for them. The proximity of their homes also makes them uncomfortable.

The Figure 8 shows that the respondents expressed very low level of satisfaction regarding their interaction with neighbors. The satisfaction level is very low in all categories as the residents did not feel safe to interact with the neighbors. Apartment residents responded that many bachelors lived in the apartment due to which they did not socialize much with the neighbors. The respondents of S. U. houses as well as apartments expressed dissatisfaction when asked whether they felt welcomed in the neighborhood.

The respondents of both the housing types expressed dissatisfaction regarding the security conditions of their homes and neighborhoods. According to the residents no security was provided to them by the administration. Some houses had their own guards or had installed security cameras. People living in sectors G10, G11 complained of robberies. Most of them complained that they did not feel safe while parking their cars in the streets especially at night. $30 \%$ respondents who were satisfied with the security mostly belonged to the apartment buildings of sector F11, F10 and F8. Management of private buildings had installed cameras on each floor of the building but the residents felt that this measure was not enough to tackle 


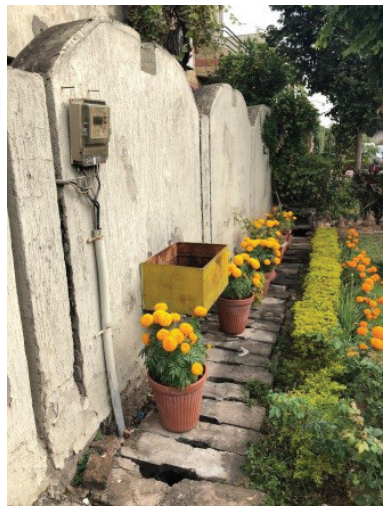

Figure 9. Garbage point in front of S.U. house

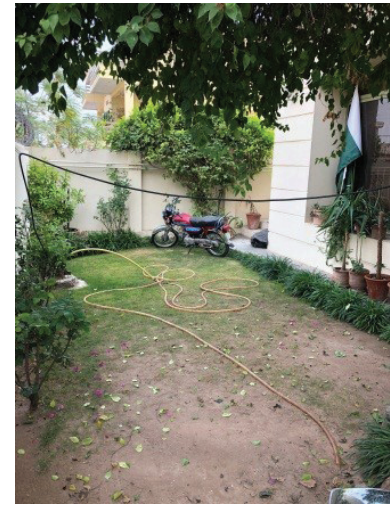

Figure 10. Front lawn in S.U. house

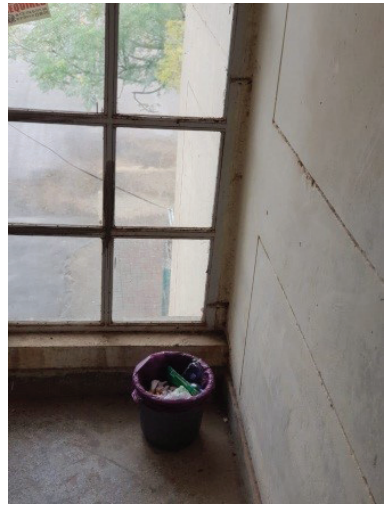

Figure 11. Garbage lying in the lobbies of apartment

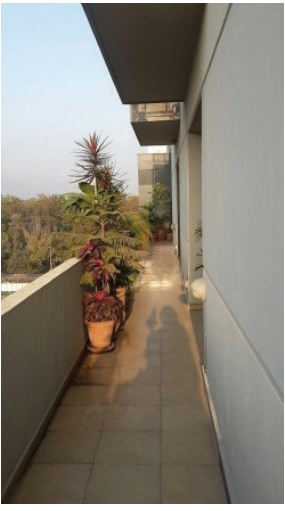

Figure 12. Balcony in apartments the issue of security. As noted, the low satisfaction was because of the low security provision by the administration. The overall situation of the country and the number of crimes committed in the capital city these days made the residents more concerned about the safety of their families.

The respondents of the S.U. houses expressed very low level of satisfaction regarding enforcement of rules by CDA. They complained that many people did not comply with the rules of CDA. Hostels and schools were being operated in their neighborhoods which created inconvenience due to excessive traffic during peak times. These illegal activities in residential areas made their neighborhoods more crowded and noisy and also disturbed their privacy. The respondents of apartments showed low level of satisfaction regarding enforcement of laws. The reason behind this was that most of the people did not follow the rules. Many buildings did not have any set of rules for the residents.

\subsection{T-test}

A t-test was conducted to explore the difference in opinion of the residents of the both housing types. Subjects were divided into 2 groups according to their housing type (Group 1: single unit house, Group 2: apartments).

This section examines the difference between residential satisfaction and house types among the sampled units. The previous section showed the variations in the residents rating of satisfaction for selected variables among different house types. This section evaluated how these variations were statistically significant. Analysis of t-test was conducted so that the difference between house type and residential satisfaction could be assessed. As shown in Table 5, the test results indicated that in 2 (out of 22) selected variables which are; noise and parking lot maintenance, the difference between house type and residential satisfaction was significant at the 0.05 probability level. This indicates that the satisfaction of the residents of the apartments and S.U. houses about noise and parking lot maintenance varies from one another significantly. This doesn't imply that there is no difference between the satisfaction level of other variables. Each variable plays an important role in the overall satisfaction of a resident of a dwelling and thus must be observed to achieve residential satisfaction.

\subsection{Regression analysis}

A simple linear regression was calculated to predict overall residential satisfaction based on the indicators mentioned in Table 1. Results of the multiple linear regression as shown in Table 6, indicate that there is a collective significant effect between the overall satisfaction and the abovementioned indicators, $\left(\mathrm{F}=26.944, p<0.001, R^{2}=0.834\right)$. The individual predictors were examined further and indicated that cleanliness of neighborhood $(t=4.036, p<.05)$, enforcement of rules $(t=2.324, p=0.022)$, garbage disposal $(t=3.077, p=0.003)$, safety $(t=2.059, p=0.042)$, visual attractiveness $(\mathrm{t}=2.522, p=0.013)$, residence size $(\mathrm{t}=2.673, p=0.009)$, privacy $(\mathrm{t}=1.997, p=0.048)$, air satisfaction $(\mathrm{t}=2.406, p=0.018)$ and overall environment $(\mathrm{t}=2.537, p=0.012)$ were significant predictors in the model.

The results suggest that there are six indicators that effect the residential satisfaction the most. Cleanliness of neighborhood has the most influence on residential satisfaction. It indicates that residents with cleaner neighborhoods are more satisfied about their residential satisfaction. Similarly, visual attractiveness of the neighborhood also plays an important part in determining the residential satisfaction of the residents. These indicators are on neighborhood level and can only be provided and taken care of by the responsible government administration i.e. $\mathrm{CDA}$ in Islamabad's case. In case of housing attributes, the results indicate that air satisfaction and residence size matter the most to the residents and thus can change the satisfaction level of the residents. Facilities like garbage disposal also play vital role in satisfaction of the residents followed by social factor like overall social environment of the neighborhood. Residential satisfaction can also be improved by taking care of the safety and enforcement of 
Table 5. T-test of significance between house type and residential satisfaction in Islamabad (source: field survey)

\begin{tabular}{|c|c|c|c|c|c|c|c|c|c|c|}
\hline & \multicolumn{2}{|c|}{$\begin{array}{l}\text { Levene's test } \\
\text { for equality of } \\
\text { variances }\end{array}$} & \multicolumn{7}{|c|}{ T-test for equality of means } \\
\hline & & \multirow[t]{2}{*}{$\mathrm{F}$} & \multirow[t]{2}{*}{ Sig. } & \multirow[t]{2}{*}{$\mathrm{T}$} & \multirow[t]{2}{*}{$\mathrm{df}$} & \multirow[t]{2}{*}{$\begin{array}{c}\text { Sig. } \\
\text { (2-tailed) }\end{array}$} & \multirow[t]{2}{*}{$\begin{array}{l}\text { Mean } \\
\text { diff. }\end{array}$} & \multirow{2}{*}{$\begin{array}{l}\text { Std. } \\
\text { Error } \\
\text { diff. }\end{array}$} & \multicolumn{2}{|c|}{$\begin{array}{l}95 \% \text { confidence } \\
\text { interval of the } \\
\text { difference }\end{array}$} \\
\hline & & & & & & & & & Lower & Upper \\
\hline Light satisfaction & $\begin{array}{l}\text { Equal variances } \\
\text { assumed }\end{array}$ & 2.5 & 0.12 & 0.76 & 145 & 0.45 & 0.18 & 0.23 & -0.28 & 0.64 \\
\hline Air satisfaction & $\begin{array}{l}\text { Equal variances } \\
\text { assumed }\end{array}$ & 0.18 & 0.67 & 0.43 & 145 & 0.67 & 0.1 & 0.23 & -0.36 & 0.56 \\
\hline Maintenance & $\begin{array}{l}\text { Equal variances } \\
\text { assumed }\end{array}$ & 2.54 & 0.11 & -1.63 & 145 & 0.1 & -0.17 & 0.1 & -0.37 & 0.04 \\
\hline $\begin{array}{l}\text { Cleanliness } \\
\text { neighbourhood }\end{array}$ & $\begin{array}{l}\text { Equal variances } \\
\text { assumed }\end{array}$ & 0.1 & 0.75 & -0.25 & 145 & 0.8 & -0.07 & 0.28 & -0.62 & 0.48 \\
\hline $\begin{array}{l}\text { Visual } \\
\text { attractiveness }\end{array}$ & $\begin{array}{l}\text { Equal variances } \\
\text { assumed }\end{array}$ & 0.38 & 0.53 & -0.8 & 145 & 0.42 & -0.17 & 0.22 & -0.6 & 0.25 \\
\hline $\begin{array}{l}\text { Building } \\
\text { maintenance }\end{array}$ & $\begin{array}{l}\text { Equal variances } \\
\text { not assumed }\end{array}$ & 8.06 & 0.01 & 1.88 & 47.71 & 0.07 & 0.36 & 0.19 & -0.02 & 0.75 \\
\hline $\begin{array}{l}\text { Street } \\
\text { maintenance }\end{array}$ & $\begin{array}{l}\text { Equal variances } \\
\text { assumed }\end{array}$ & 0.91 & 0.34 & 0 & 145 & 1 & 0 & 0.28 & -0.55 & 0.55 \\
\hline $\begin{array}{l}\text { Accessibility for } \\
\text { handicap }\end{array}$ & $\begin{array}{l}\text { Equal variances } \\
\text { not assumed }\end{array}$ & 15.82 & 0 & -0.59 & 59.46 & 0.56 & -0.12 & 0.21 & -0.54 & 0.3 \\
\hline Security & $\begin{array}{l}\text { Equal variances } \\
\text { assumed }\end{array}$ & 0.18 & 0.66 & 0.59 & 145 & 0.55 & 0.16 & 0.27 & -0.37 & 0.7 \\
\hline Safety & $\begin{array}{l}\text { Equal variances } \\
\text { assumed }\end{array}$ & 2.83 & 0.09 & -0.29 & 145 & 0.77 & -0.08 & 0.29 & -0.65 & 0.48 \\
\hline $\begin{array}{l}\text { Enforcement of } \\
\text { rules }\end{array}$ & $\begin{array}{l}\text { Equal variances } \\
\text { assumed }\end{array}$ & 0.18 & 0.67 & -1.27 & 145 & 0.21 & -0.34 & 0.27 & -0.88 & 0.19 \\
\hline Garbage disposal & $\begin{array}{l}\text { Equal variances } \\
\text { assumed }\end{array}$ & 1.29 & 0.26 & 1.84 & 145 & 0.07 & 0.51 & 0.28 & -0.04 & 1.06 \\
\hline Water supply & $\begin{array}{l}\text { Equal variances } \\
\text { assumed }\end{array}$ & 2.22 & 0.14 & 0.78 & 145 & 0.44 & 0.22 & 0.28 & -0.33 & 0.76 \\
\hline Residence size & $\begin{array}{l}\text { Equal variances } \\
\text { assumed }\end{array}$ & 0.02 & 0.88 & -1.72 & 145 & 0.09 & -0.51 & 0.3 & -1.1 & 0.08 \\
\hline Privacy & $\begin{array}{l}\text { Equal variance not } \\
\text { assumed }\end{array}$ & 4.204 & 0.04 & 0.26 & 53.58 & 0.8 & 0.05 & 0.21 & -0.36 & 0.47 \\
\hline $\begin{array}{l}\text { Size of open } \\
\text { space }\end{array}$ & $\begin{array}{l}\text { Equal variances } \\
\text { assumed }\end{array}$ & 0.001 & 0.98 & 1.1 & 145 & 0.27 & 0.26 & 0.23 & -0.21 & 0.72 \\
\hline Noise & $\begin{array}{l}\text { Equal variances } \\
\text { assumed }\end{array}$ & 0.001 & 0.97 & 2.05 & 145 & 0.04 & 0.57 & 0.28 & 0.02 & 1.12 \\
\hline $\begin{array}{l}\text { Parking lot } \\
\text { maintenance }\end{array}$ & $\begin{array}{l}\text { Equal variance not } \\
\text { assume }\end{array}$ & 12.83 & 0 & 3.83 & 59.62 & 0 & 0.82 & 0.22 & 0.39 & 1.25 \\
\hline $\begin{array}{l}\text { Interaction with } \\
\text { neighbours }\end{array}$ & $\begin{array}{l}\text { Equal variances } \\
\text { assumed }\end{array}$ & 3.3 & 0.07 & 0.6 & 145 & 0.55 & 0.17 & 0.28 & -0.38 & 0.72 \\
\hline $\begin{array}{l}\text { Physical } \\
\text { condition }\end{array}$ & $\begin{array}{l}\text { Equal variance not } \\
\text { assumed }\end{array}$ & 15.514 & 0 & -1.85 & 61.62 & 0.07 & -0.41 & 0.22 & -0.86 & 0.03 \\
\hline Welcoming & $\begin{array}{l}\text { Equal variances } \\
\text { assumed }\end{array}$ & 0.16 & 0.68 & 0.49 & 145 & 0.63 & 0.1 & 0.2 & -0.3 & 0.5 \\
\hline
\end{tabular}


Table 6. Regression analysis for overall residence satisfaction

\begin{tabular}{|c|c|c|c|c|c|}
\hline \multirow{2}{*}{ Model } & \multicolumn{2}{|c|}{ Unstandardized coefficients } & \multirow{2}{*}{$\begin{array}{c}\begin{array}{c}\text { Standardized } \\
\text { coefficients }\end{array} \\
\text { Beta }\end{array}$} & \multirow{2}{*}{$\mathrm{t}$} & \multirow{2}{*}{ Sig. } \\
\hline & B & Std. Error & & & \\
\hline Overall satisfaction & -0.049 & 0.219 & & -0.222 & 0.825 \\
\hline \multicolumn{6}{|l|}{ Housing attributes } \\
\hline Light satisfaction & 0.016 & 0.030 & 0.025 & 0.539 & 0.591 \\
\hline Air satisfaction & 0.076 & 0.032 & 0.116 & 2.406 & 0.018 \\
\hline Residence size & 0.062 & 0.023 & 0.122 & 2.673 & 0.009 \\
\hline Size of open space & 0.006 & 0.034 & 0.010 & 0.190 & 0.850 \\
\hline \multicolumn{6}{|l|}{ Neighborhood } \\
\hline Visual attractiveness & 0.091 & 0.036 & 0.130 & 2.533 & 0.013 \\
\hline Cleanliness of neighborhood & 0.106 & 0.026 & 0.193 & 4.036 & 0.000 \\
\hline Recreational space & 0.045 & 0.030 & 0.061 & 1.491 & 0.139 \\
\hline \multicolumn{6}{|l|}{ Facilities } \\
\hline Accessibility for handicaps & 0.030 & 0.027 & 0.055 & 1.103 & 0.272 \\
\hline Garbage disposal & 0.074 & 0.024 & 0.137 & 3.077 & 0.003 \\
\hline Water supply & 0.046 & 0.026 & 0.085 & 1.813 & 0.072 \\
\hline \multicolumn{6}{|l|}{ Maintenance } \\
\hline Building maintenance & 0.039 & 0.033 & 0.059 & 1.185 & 0.238 \\
\hline Street maintenance & 0.038 & 0.028 & 0.070 & 1.349 & 0.180 \\
\hline Parking lot maintenance & -0.006 & 0.025 & -0.012 & -0.255 & 0.800 \\
\hline \multicolumn{6}{|l|}{ Safety } \\
\hline Security & 0.041 & 0.025 & 0.073 & 1.604 & 0.111 \\
\hline Safety & 0.073 & 0.035 & 0.137 & 2.059 & 0.042 \\
\hline Enforcement of rules & 0.085 & 0.037 & 0.153 & 2.324 & 0.022 \\
\hline \multicolumn{6}{|l|}{ Social/psychological } \\
\hline Privacy & 0.069 & 0.035 & 0.119 & 1.997 & 0.048 \\
\hline Noise & 0.026 & 0.023 & 0.048 & 1.116 & 0.267 \\
\hline Interaction with neighbors & 0.022 & 0.025 & 0.041 & 0.874 & 0.384 \\
\hline Overall environment & 0.083 & 0.033 & 0.111 & 2.537 & 0.012 \\
\hline \multicolumn{6}{|l|}{ Socio-economic } \\
\hline Age & 0.023 & 0.020 & 0.044 & 1.120 & 0.265 \\
\hline Education & -0.004 & 0.034 & -0.005 & -0.114 & 0.909 \\
\hline Number of residents & 0.007 & 0.046 & 0.008 & 0.154 & 0.878 \\
\hline People employed & 0.052 & 0.028 & 0.076 & 1.835 & 0.069 \\
\hline Workplace/education distance & -0.001 & 0.020 & -0.003 & -0.074 & 0.941 \\
\hline Monthly income & 0.001 & 0.013 & 0.002 & 0.058 & 0.954 \\
\hline No. of Cars & 0.015 & 0.030 & 0.020 & 0.484 & 0.629 \\
\hline Duration of stay & -0.031 & 0.016 & -0.075 & -1.903 & 0.059 \\
\hline
\end{tabular}

rules by the administration. The results also conclude that privacy and overall environment of the neighborhood also play vital role in improving the residential satisfaction of the residents.

The results also show that overall satisfaction of the residents had an inverse relationship with education, monthly income and duration of stay of the residents. The negative relationship between education and residential satisfaction may reflect the fact that better educated respondents tend to have higher standards and aspirations which make them less satisfied with the residences. Similarly, negative relationship between monthly income and residential satisfaction can be explained by the fact that better households tend to have higher aspirations relative to their current standard of housing, which in turn can lower their residential satisfaction.

\subsection{Factors affecting the preference of residents in case of apartments}

When asked about the reasons that would encourage the 


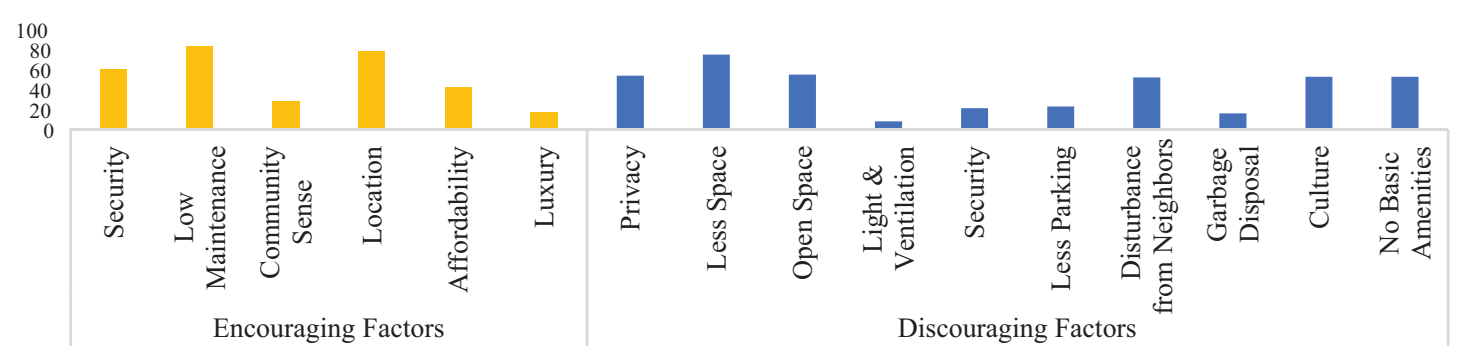

Figure 13. Factors affecting the preference of residents regarding apartment buildings (source: filed survey)

residents to shift to an apartment; a variety of responses were recorded. $60 \%$ of the respondents thought that apartments were more secure. $83 \%$ thought they required minimum maintenance owing to the small size of the dwelling. $28 \%$ of the respondents thought that living in apartment buildings helped in developing a sense of community and brings people closer. $79 \%$ suggested that the location of the apartments might encourage them to shift to one. $42 \%$ of the respondents thought that apartments were more affordable and thus they would switch for a more affordable option while, only $17 \%$ respondents stated that luxury might be a reason that would encourage them to shift as shown in Figure 13.

The residents were then asked about the factors that would discourage them to shift to an apartment. Almost $50 \%$ of the residents stated that disturbance from the neighbors, privacy issues, less open space, culture and absence of basic amenities are some of the problems they think they might face in an apartment building. The respondents stated that presence of basic amenities like lifts, water supply, maintenance, cleanliness of buildings etc. are very important for choosing an apartment building. While $75 \%$ responded that smaller sizes of the apartments create inconvenience and thus, would discourage them to live in an apartment. Problems like absence of proper light and ventilation, security, less parking space and garbage disposal was highlighted by almost $20 \%$ of the respondents.

It shows that by solving above mentioned issues we can change the perception of the people about apartment buildings and would encourage them to move to one in future.

\section{Conclusions}

In conclusion, this study showed that the socioeconomic status of the residents of the S.U. houses was better than those living in the apartments. Similarly, the residents of the S.U. houses have been living longer in the city. The study found medium level of satisfaction in terms of light, air, size of open space and privacy in both housing types. The residents of S.U. houses stated dissatisfaction in terms of residence size, security and over all culture and low level of satisfaction in terms of cleanliness of neighborhood, visual attractiveness of neighborhood, water supply and building maintenance. Very low level of satisfaction was observed for accessibility for handicap, street maintenance, and noise, interaction with neighbors, safety and enforcement of rules. The residents of apartments expressed low level of satisfaction in terms of residence size, welcoming culture and enforcement of rules. Very low level of satisfaction was observed in terms of safety, interaction with neighbors, buildings and street maintenance, water supply, accessibility for handicap, recreational space and cleanliness of neighborhood. The residents were dissatisfied in terms of garbage disposal, parking lot maintenance, noise and security.

Overall only significant variance was found between the level of satisfaction of noise, parking lot maintenance and cleanliness of buildings of both housing types. After analyzing the data, it was concluded that there are a number of factors that should be considered while designing and executing a residential project in an urban setting. Issues such as privacy, open space, ventilation, noise, garbage disposal should be dealt with as these are the most important factors that affect a resident's perspective about the apartment buildings.

The results of the regression analysis showed that cleanliness of neighborhood, enforcement of rules, garbage disposal, safety, visual attractiveness, privacy, air satisfaction and overall satisfaction with the social fabric of the neighborhood plays an important role in the residential satisfaction of the residents. Residential satisfaction was found to be positively associated with the abovementioned indicators.

The results of this study demonstrated that the residents of different housing types had different preferences and there is a need for adequate consideration by designers and housing planners to the preferences of all social groups. Architects and planners should collaborate with each other to come up with better solution for the problems of the city. Currently the government of Pakistan is proposing to build 5,000,000 affordable residential units for the lower income group of Pakistan. This study would help the policy makers in understanding the gap between the quality of housing and residential satisfaction of residents. Provision of basic amenities might encourage people to opt for apartments buildings over single housing units. The choice of people must be respected and incorporated in new developmental projects for providing better solutions and successful implementation of these projects (Brunn, Williams, \& Zeigler, 2003).

This research is no doubt not without limitations. The sample size taken for this study was comparatively smaller due to the current security situation of the country. A bigger sample size might give more detailed view of the problems faced by the residents. Price of the residential units and 
government intervention were not considered. Thus, it is suggested that these factors are included in future research. Nevertheless, this study is the first of its kind, to the best of our knowledge, conducted on the residents of apartments and single unit houses in Islamabad, the capital of Pakistan. In the future, further research should be conducted in cities like Karachi and Lahore to observe the housing trend there.

\section{References}

Abdu, A., Hashim, A. H., Samah, A. A., \& Salim, A. S. S. (2014). Relationship between background characteristics and residential satisfaction of young households in unplanned neighbourhoods in Kano, Nigeria. Journal of Humanities and Social Science, 19(10), 138-145.

https://doi.org/10.9790/0837-19108138145

Addo, I. A. (2016). Assessing residential satisfaction among low income households in multi-habited dwellings in selected low income communities in Accra. Urban Studies, 53(4), 631-650. https://doi.org/10.1177/0042098015571055

Adriaanse, C. (2007). Measuring residential satisfaction: a residential environmental satisfaction scale (RESS). Journal of Housing and the Built Environment, 22(3), 287. https://doi.org/10.1007/s10901-007-9082-9

Amérigo, M., \& Aragonés, J. I. (1988). Satisfacción residencial en un barrio remodelado: predictores físicos y sociales. Revista de Psicología Social, 3(1), 61-70. https://doi.org/10.1080/02134748.1988.10821574

Amérigo, M., \& Aragonés, J. I. (1990). Residential satisfaction in council housing. Journal of Environmental Psychology, 10(4), 313-325. https://doi.org/10.1016/S0272-4944(05)80031-3

Amérigo, M., \& Aragones, J. I. (1997). A theoretical and methodological approach to the study of residential satisfaction. Journal of Environmental Psychology, 17(1), 47-57. https://doi.org/10.1006/jevp.1996.0038

Amole, D. (2009). Residential satisfaction in students' housing. Journal of Environmental Psychology, 29(1), 76-85.

Anwar, H. N., Perveen, S., Mehmood, S., \& Akhtar, S. (2008). Assessment of farmer's attitude towards participatory irrigation management in Punjab-Pakistan. Pakistan Journal of Life and Social Sciences, 6(2), 121-126.

Aragonés, J., Corraliza, J., Cortés, B., \& Amérigo, M. (1992). Perception of territory and social identity. Socio-Environmental Metamorphoses: Builtscape, Landscape, Ethnoscape, Euroscape, 12, 252-259.

Azimi, N., \& Esmaeilzadeh, Y. (2017). Assessing the relationship between house types and residential satisfaction in Tabriz, Iran. International Journal of Urban Sciences, 21(2), 185-203. https://doi.org/10.1080/12265934.2016.1273128

Baiden, P., Arku, G., Luginaah, I., \& Asiedu, A. B. (2011). An assessment of residents' housing satisfaction and coping in Accra, Ghana. Journal of Public Health, 19(1), 29-37. https://doi.org/10.1007/s10389-010-0348-4

Baillie, S. (1990). Dwelling features as intervening variables in housing satisfaction and propensity to move. Housing and Society, 17(3), 1-15. https://doi.org/10.1080/08882746.1990.11430077

Bonaiuto, M., Aiello, A., Perugini, M., Bonnes, M., \& Ercolani, A. P. (1999). Multidimensional perception of residential environment quality and neighbourhood attachment in the urban environment. Journal of Environmental Psychology, 19(4), 331-352. https://doi.org/10.1006/jevp.1999.0138

Bonnes, M., Bonaiuto, M., \& Ercolani, A. P. (1991). Crowding and residential satisfaction in the urban environment: a con- textual approach. Environment and Behavior, 23(5), 531-552. https://doi.org/10.1177/0013916591235001

Braubach, M. (2007). Residential conditions and their impact on residential environment satisfaction and health: results of the WHO large analysis and review of European housing and health status (LARES) study. International Journal of Environment and Pollution, 30(3-4), 384-403.

https://doi.org/10.1504/IJEP.2007.014817

Brunn, S. D., Williams, J. F., \& Zeigler, D. J. (2003). Cities of the world: world regional urban development. USA: Rowman \& Littlefield.

Butt, M. J., Waqas, A., Iqbal, M. F., Muhammad, G., \& Lodhi, M. (2012). Assessment of urban sprawl of Islamabad metropolitan area using multi-sensor and multi-temporal satellite data. Arabian Journal for Science and Engineering, 37(1), 101-114. https://doi.org/10.1007/s13369-011-0148-3

Chapman, D. W., \& Lombard, J. R. (2006). Determinants of neighborhood satisfaction in fee-based gated and nongated communities. Urban Affairs Review, 41(6), 769-799. https://doi.org/10.1177/1078087406287164

Coker, A., Awokola, O., Olomolaiye, P., \& Booth, C. (2008). Challenges of urban housing quality and its associations with neighbourhood environments: insights and exepriences of Ibadan City, Nigeria. Journal of Environmental Health Research, 7(1), 21-30.

da Luz Reis, A. T., \& Dias Lay, M. C. (2010). Internal and external aesthetics of housing estates. Environment and Behavior, 42(2), 271-294. https://doi.org/10.1177/0013916509334134

Deshmukh, J. (1995). Housing satisfaction: a cross-cultural study of married student housing. Paper presented at the Proceedings of the 26th Annual Environmental Design Research Association Conference. Oklahoma City, OK, The Association.

Diaz-Serrano, L. (2006, September). Housing satisfaction, homeownership and housing mobility: a panel data analysis for twelve EU countries (IZA Discussion Paper No. 2318, pp. 1-45). Bonn: Institute for the Study of Labor (IZA). Retrieved from https://pdfs.semanticscholar.org/5e16/9620656c5ed813e 34c9546edb32886082276.pdf

Diaz-Serrano, L., \& Rodríguez-Pose, A. (2011, April). Decentralization, happiness, and the perception of institutions (IZA Discussion Paper No. 5647, pp. 1-41). Bonn: Institute for the Study of Labor (IZA). Retrieved from http://ftp.iza.org/dp5647.pdf

Ewing, R., Bartholomew, K., Winkelman, S., Walters, J., Chen, D., McCann, B., \& Goldberg, D. (2007). Growing cooler: the evidence on urban development and climate change. Washington, D.C.: Urban Land Institute.

Fried, M., \& Gleicher, G. (1972). Molding behaviour to fit the environment: adaptation to the familiar and unfamiliar. In Environmental Psychology (pp. 221-264). Philadelphia: WB Saunders Company.

Galster, G. (1987). Identifying the correlates of dwelling satisfaction: an empirical critique. Environment and Behavior, 19(5), 539-568. https://doi.org/10.1177/0013916587195001

Gifford, R. (2007). The Consequences of living in high-rise buildings. Architectural Science Review, 50(1), 2-17. https://doi.org/10.3763/asre.2007.5002

Goudy, W. J. (1977). Evaluations of local attributes and community satisfaction in small towns. Rural Sociology, 42(3), 371-382.

Guney, Y. (1997). The evaluation of high-rise residents' satisfaction in Turkey. Paper presented at the Proceedings of EDRA. Oklahoma City, OK, The Association.

Hu, F. (2013). Homeownership and subjective wellbeing in urban China: does owning a house make you happier? Social Indicators Research, 110(3), 951-971. https://doi.org/10.1007/s11205-011-9967-6 
Jaafar, M., Mohamad, O., Liza Hasan, N., \& Ramayah, T. (2005). The determinants of housing satisfaction level: a study on residential development project by Penang development corporation (PDC). Malaysia: Universiti Teknologi Malaysia.

Jabeen, A., Sheng, H. X., \& Aamir, M. (2015). Housing crises in Pakistan: review of population growth and deficiencies in housing laws and policies. International Journal of Sciences: Basic and Applied Research (IJSBAR), 24(3), 323-347.

Kiel, K., \& Carson, R. (1990). An examination of systematic differences in the appreciation of individual housing units. Journal of Real Estate Research, 5(3), 301-318.

Lewicka, M. (2011). Place attachment: how far have we come in the last 40 years? Journal of Environmental Psychology, 31(3), 207-230. https://doi.org/10.1016/j.jenvp.2010.10.001

Li, Z., \& Wu, F. (2013). Residential satisfaction in China's informal settlements: a case study of Beijing, Shanghai, and Guangzhou. Urban Geography, 34(7), 923-949. https://doi.org/10.1080/02723638.2013.778694

Lu, M. (1999). Determinants of residential satisfaction: ordered logit vs. regression models. Growth and Change, 30(2), 264287. https://doi.org/10.1111/0017-4815.00113

Mahsud, A. Z. K. (2007). Representing the state: symbolism and ideology in Doxiadis' plan for Islamabad. London: Routlegde.

Marans, R. W. (2003). Understanding environmental quality through quality of life studies: the 2001 DAS and its use of subjective and objective indicators. Landscape and Urban Planning, 65(1-2), 73-83. https://doi.org/10.1016/S0169-2046(02)00239-6

Mohit, M. A., Ibrahim, M., \& Rashid, Y. R. (2010). Assessment of residential satisfaction in newly designed public low-cost housing in Kuala Lumpur, Malaysia. Habitat International, 34(1), 18-27. https://doi.org/10.1016/j.habitatint.2009.04.002

Morris, E. W., \& Winter, M. (1978). Housing, family, and society. Hoboken, New Jersey: John Wiley and Sons.

Mulvihill, R. (1977). The relative importance of elements of lowrise hosuing estates (Planning Division Working Paper 1). Dublin, Forbartha.

Nadim, H. (2014). Land mafia and housing societies. The Express Tribune. Retrieved from https://tribune.com.pk/story/703320/ land-mafias-and-housing-societies/

Onibokun, A. G. (1976). Social system correlates of residential satisfaction. Environment and Behavior, 8(3), 323-344. https://doi.org/10.1177/136327527600800301

Pakistan Bureau of Statistics. (2017). District and tehsil level population summary with region breakup. Retrieved from http:// www.pbscensus.gov.pk/sites/default/files/bwpsr/islamabad/ ISLAMABAD_SUMMARY.pdf

Peck, C., \& Kay Stewart, K. (1985). Satisfaction with housing and quality of life. Home Economics Research Journal, 13(4), 363372. https://doi.org/10.1177/1077727X8501300403

Potter, J., \& Cantarero, R. (2006). How does increasing population and diversity affect resident satisfaction? A small community case study. Environment and Behavior, 38(5), 605-625. https://doi.org/10.1177/0013916505284797

Rahman, M. S., Hussain, B., Uddin, A. M., \& Islam, N. (2015). Exploring residents' satisfaction of facilities provided by private apartment companies. Asia Pacific Management Review, 20(3), 130-140. https://doi.org/10.1016/j.apmrv.2014.12.012

Rapoport, A. (1997). Human aspects of urban form: towards a man-environment approach to urban form and design. Contemporary Sociology, 8(2), 313-314. https://doi.org/10.2307/2066198
Rent, G. S., \& Rent, C. S. (1978). Low-income housing: factors related to residential satisfaction. Environment and Behavior, 10(4), 459-488. https://doi.org/10.1177/001391657801000401

Rioux, L., \& Werner, C. (2011). Residential satisfaction among aging people living in place. Journal of Environmental Psychology, 31(2), 158-169.

https://doi.org/10.1016/j.jenvp.2010.12.001

Rohe, W. M., \& Basolo, V. (1997). Long-term effects of homeownership on the self-perceptions and social interaction of low-income persons. Environment and Behavior, 29(6), 793819. https://doi.org/10.1177/0013916597296004

Roscoe, J. T. (1975). Fundamental research statistics for the behavioral sciences (2nd ed.). New York : Holt, Rinehart and Winston.

Sawas, M. A., Anwar, N. H., Iqtidar, H., \& Viqar, M. S. (2014). Urbanization, gender and violence in Rawalpindi and Islamabad: a scoping study. UK: Department of Geography, King's College London.

Tran, T. Q., \& Van Vu, H. (2018). A microeconometric analysis of housing and life satisfaction among the Vietnamese elderly. Quality \& Quantity, 52(2), 849-867. https://doi.org/10.1007/s11135-017-0492-9

Varady, D. P., \& Preiser, W. F. (1998). Scattered-site public housing and housing satisfaction: implications for the new public housing program. Journal of the American Planning Association, 64(2), 189-207. https://doi.org/10.1080/01944369808975975

Varady, D. P., Walker, C. C., \& Wang, X. (2001). Voucher recipient achievement of improved housing conditions in the US: do moving distance and relocation services matter? Urban Studies, 38(8), 1273-1304. https://doi.org/10.1080/00420980124918

Vera-Toscano, E., \& Ateca-Amestoy, V. (2008). The relevance of social interactions on housing satisfaction. Social Indicators Research, 86(2), 257-274. https://doi.org/10.1007/s11205-007-9107-5

World Bank. (2018). Project appraisal document on a proposed credit in the amount of SDR99.6 million US\$145 million equivalent to the Islamic Republic of Pakistan for a Pakistan housing finance project. World Bank.

Yamane, T. (1967). Statistics: an introductory analysis (2nd ed.). New York City, U.S: Harper and Row.

Yakas, O. (2001). Islamabad: the birth of a capital. Oxford: Oxford University Press.

Yeh, S. H. (1972). Homes for the people: a study of tenants' views on public housing in Singapore. US: Government Printing Office.

Yeh, S. H. K. (1975). Public housing in Singapore: a multidisciplinary study. Singapore: Singapore University Press.

Yi, C.-c. (1985). Urban housing satisfaction in a transitional society: a case study in Taichung, Taiwan. Urban Studies, 22(1), 1-12. https://doi.org/10.1080/00420988520080011

Zhu, L. Y., \& Shelton, G. G. (1996). The relationship of housing costs and quality to housing satisfaction of older American homeowners: regional and racial differences. Housing and Society, 23(2), 15-35. https://doi.org/10.1080/08882746.1996.11430239

\section{Notations}

\section{Abbreviations}

CDA - Capital Development Authority

KP - Khyber Pakhtunkhwa

S.U. - Single Unit 